\title{
POLK wt Allele
}

National Cancer Institute

\section{Source}

National Cancer Institute. POLK wt Allele. NCI Thesaurus. Code C106241.

Human POLK wild-type allele is located in the vicinity of $5 q 13$ and is approximately $89 \mathrm{~kb}$ in length. This allele, which encodes DNA polymerase kappa protein, plays a role in the repair of DNA damage during DNA replication. 